\author{
M. WOLSKA-PYŚ, I. CISZEWSKA
}

\title{
CHANGES IN MESOZOOPLANKTON OF THE SOUTHERN BALTIC IN 1979-1988
}

\author{
Institute of Environment Protection, Gdanisk, Poland
}

Composition, abundance, biomass and vertical distribution of mesozooplankton are compared over a ten-year period using data collected in the Gdańsk, Gotland, and Bornholm Deeps in 1979-1988. Some changes in the dominance structure among Copepoda were observed. Biomass values, compared with earlier data, were high.

\section{INTRODUCTION}

The international programme of studies in the Baltic Sea, the so-called Baltic Monitoring Programme (BMP), was initiated in 1979, the Institute of Environmental Protection being - from the beginning - a Polish contributor to BMP. The main objective of the programme is a continuous collection and assessment of data on biotic and abiotic parameters in chosen regions of the Baltic Sea in order to detect possible changes. BMP is of a great importance for estimating the extent to which the marine environment becomes degraded and for taking appropriate measures to inhibit futher degradation.

The long duration and regularity of sampling allowed the authors to generally characterize the mesozooplankton in open waters of the Southern Baltic over the past ten years. This paper presents some of the most importants elements of this analysis. The following four zooplankter groups are considered: the Copepoda (copepodites I-VI and nauplii), Cladocera, Rotatoria, and Varia.

\section{MATERIALS AND METHODS}

Data on abundance and composition were collected following recommendations of the Helsinki Commission (Anonymus 1980, 1984) in 1979-1988 at three international monitoring stations located in the central part of the Gdańsk and Bornholm Deeps and in the southern part of the Gotland Deep (Fig. 1). At the first stage of BMP (1979-1983) 


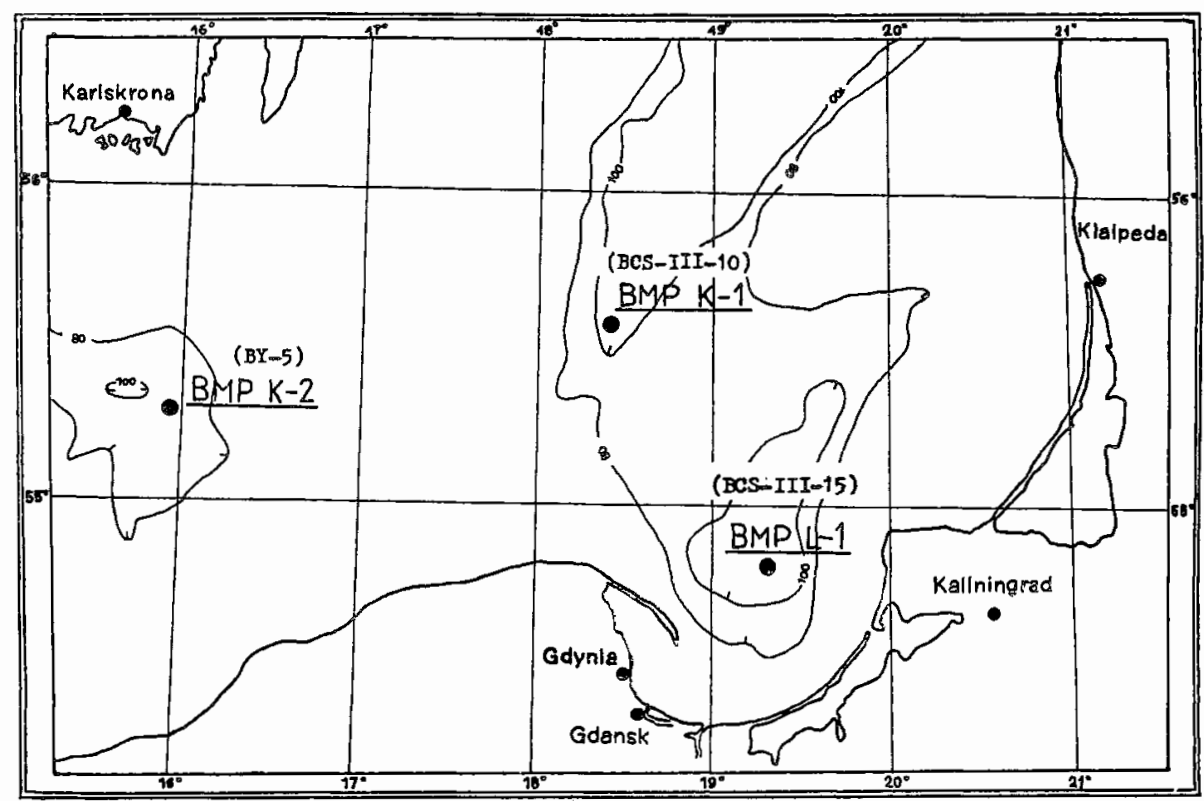

Fig. 1. Location of sampling stations

the data were collected 4 times a year, i.e. at the end of: winter, spring, summer, and in autumn. The samples were taken with a $100 \mu \mathrm{m}$ mesh size WP-2 net hauled vertically through the following water layers: $0-25 \mathrm{~m} ; 25-50 \mathrm{~m}$; and $50 \mathrm{~m}$ - bottom. In 1984-1988 (the second stage of BMP), the samples were collected 6 times a year (additionally in April and July) from the following four water layers: 0-10 m; 10-25 m; 25-50 and $50 \mathrm{~m}$ - bottom. The samples were split into two subsamples with a Folsom sample splitter. Each subsample contained at least 500 individuals; all of them were counted and identified.

Data for zooplankton biomass estimation were collected within 1982-1988. Samples taken with a $200 \mu \mathrm{m}$ mesh size WP-2 closing net were taken; biomass was determined with the volumetric displacement technique.

The values presented in this paper are means calculated from the data gathered at the three stations visited (Fig. 1).

\section{RESULTS AND DISCUSSION}

Species composition

A total of 24 species and higher taxa of zooplankters were identified, including 11 copepod taxa, 5 cladoceran species, and 2 rotifer genera; one ctenophore species 


\section{a) abundance (1979-1988)}
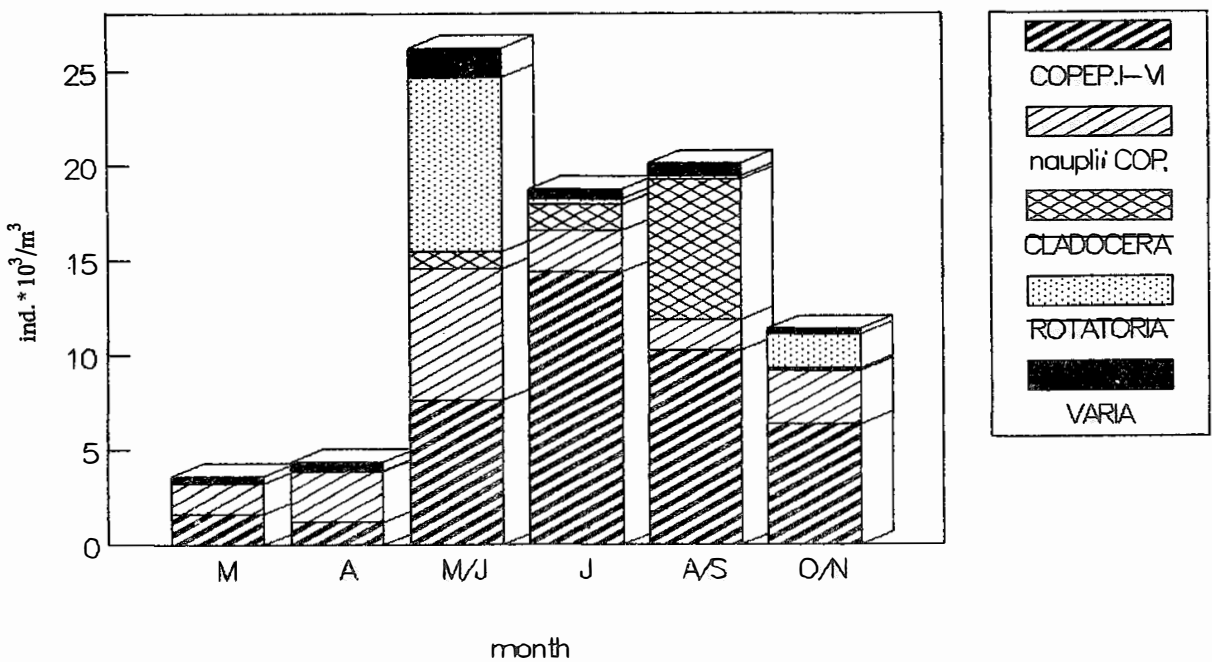

b) biomass (1982-1988)

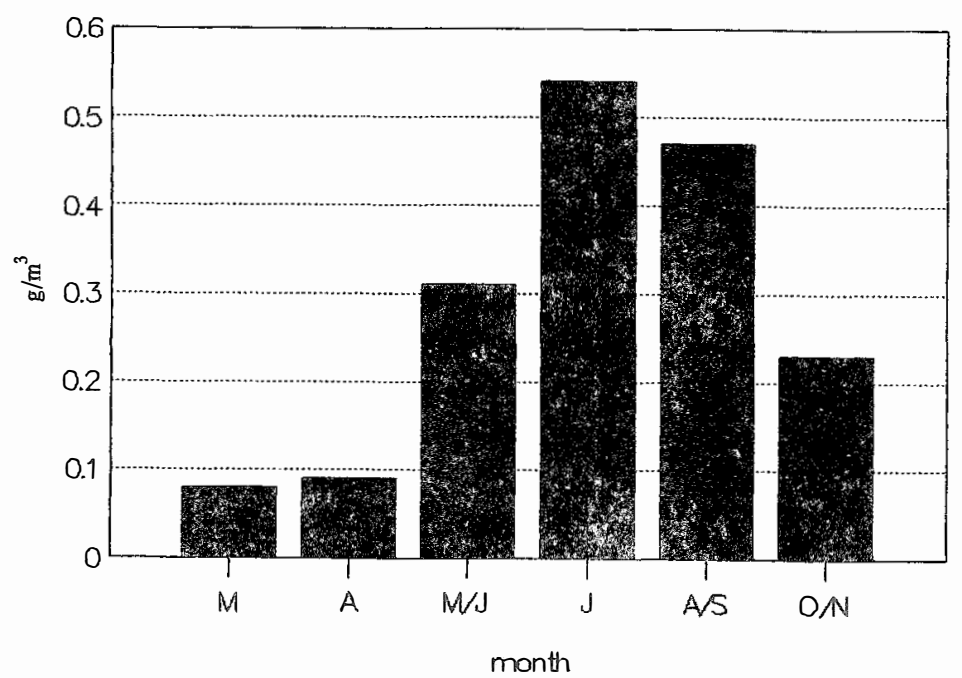

Fig. 2. Seasonal changes in zonplankton abundance

(a) and biomass, (b) (water column averages) 
and one appendicularian species were also identified. Additionally, larvae of the following benthic taxa were represented in samples: the Bivalvia, Gastropoda, Polychaeta, and Cirripedia (Balanus sp.). The main zooplanktersin the open waters of the Southern Baltic are copepods such as Pseudocalanus elongatus (Boeck), Temora longicornis (Müller), Acartia spp., and additionally, in the warm season of the year, cladocerans such as Bosmina coregoni maritima (Müller) and Evadne nordmanni (Loven) as well as rotifers of the genus Synchaeta. Besides, Fritillaria borealis (Lohmann) and larvae of the Polychaeta were common components of the zooplankton community.

Seasonal variability

The zooplankton abundance was at its lowest in March and April, the species diversity being very low then (Fig. 2a), with the Copepoda as almost the only taxon present. The copepod nauplii contributed about $50 \%$ to the total zooplankton abundance.

In May and June, the mesozooplankton abundance increased markedly, which was related to an increase in water temperature and to the increasing quantities of phytoplankton. The species diversity was high. The Rotatoria of the genus Synchoeta grew intensively in abundance then; they were particularly numerous in 1983 and 1984. The Cladocera were dominated by Evadne nordmanni.

July was a period of the highest abundance of copepod stages I-VI. On the other hand, the abundance of nauplii distinctly decreased.

In August - September, the abundance of zooplankton increased slightly due to a mass occurrence of the cladoceran Bosmina coregoni maritima.

In October - November, a clear decrease in zooplank ton abundance was observed. At the same time, the Rotatoria peaked for the second time, the peak being weaker than that in spring. Cladocerans were recorded only sporadically.

Similarly to the abundance, the zooplankton ibiomass varied markedly from season to season (Fig. 2b), the variability being predominantly concomittant with changes in the copepod abundance. The lowest zooplankton biomass (mean values for 1982-1988) was recorded in March and April (below $0.10 \mathrm{~g} / \mathrm{m}^{3}$ ), the highest biomass $\left(0.54 \mathrm{~g} / \mathrm{m}^{3}\right.$ ) occurring in July.

\section{Vertical distribution}

Thermal stratification of the Baltic waters, the presence of the halocline, and non-uniform distribution of phytoplankton are the reasons for the variability in zooplankton distribution (Drzycimski and Siudziński 1977; Koszteyn 1985; Mańkowski 1978). Due to the fact that the sampling technique was changed during the period of study, Figs 3 and 4 are based on data collected in 1984-1988 only. 

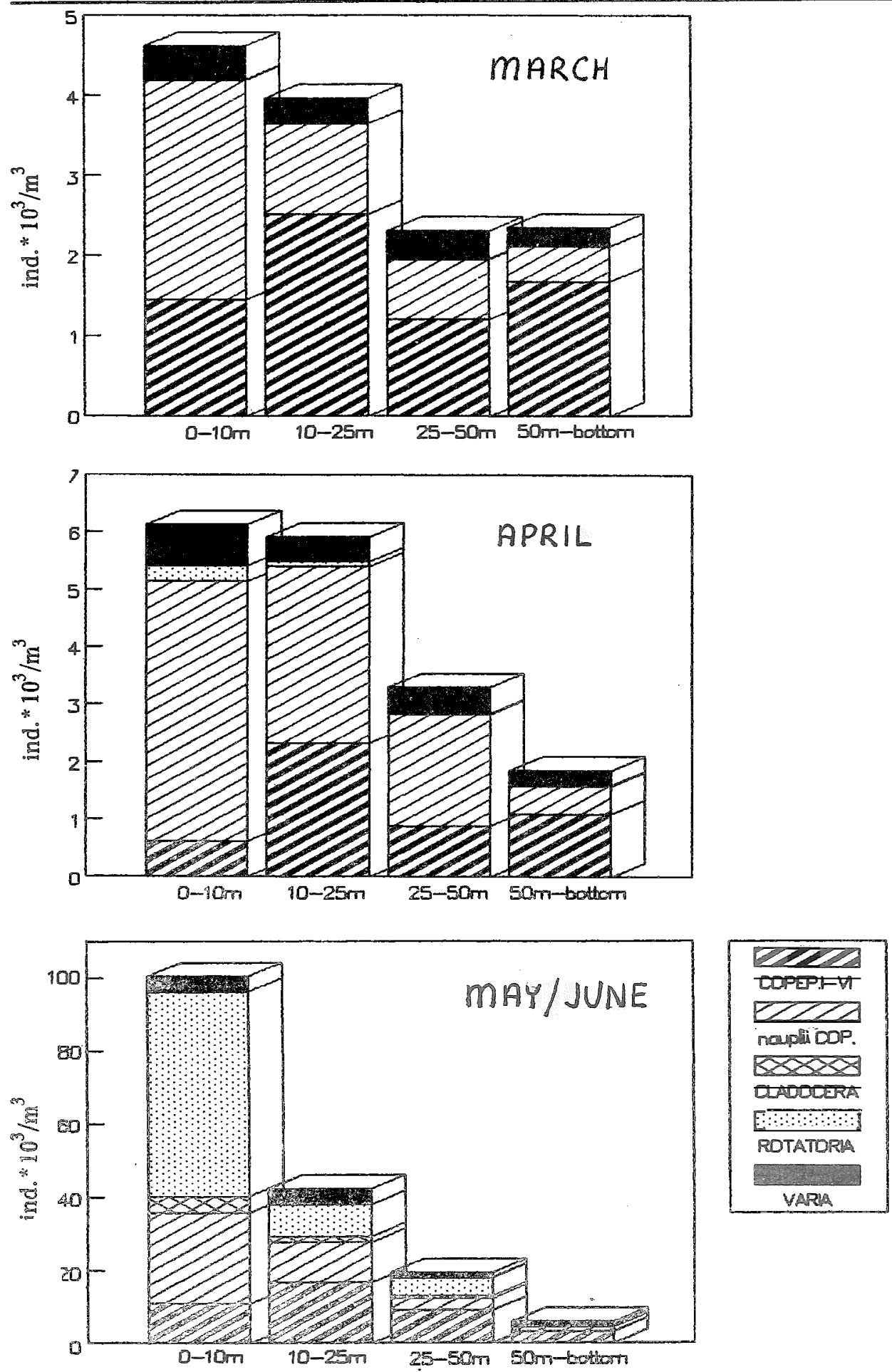

Fig. 3. Vertical distribution of zooplankton abundance in Marck, Argil, and May - Inne 

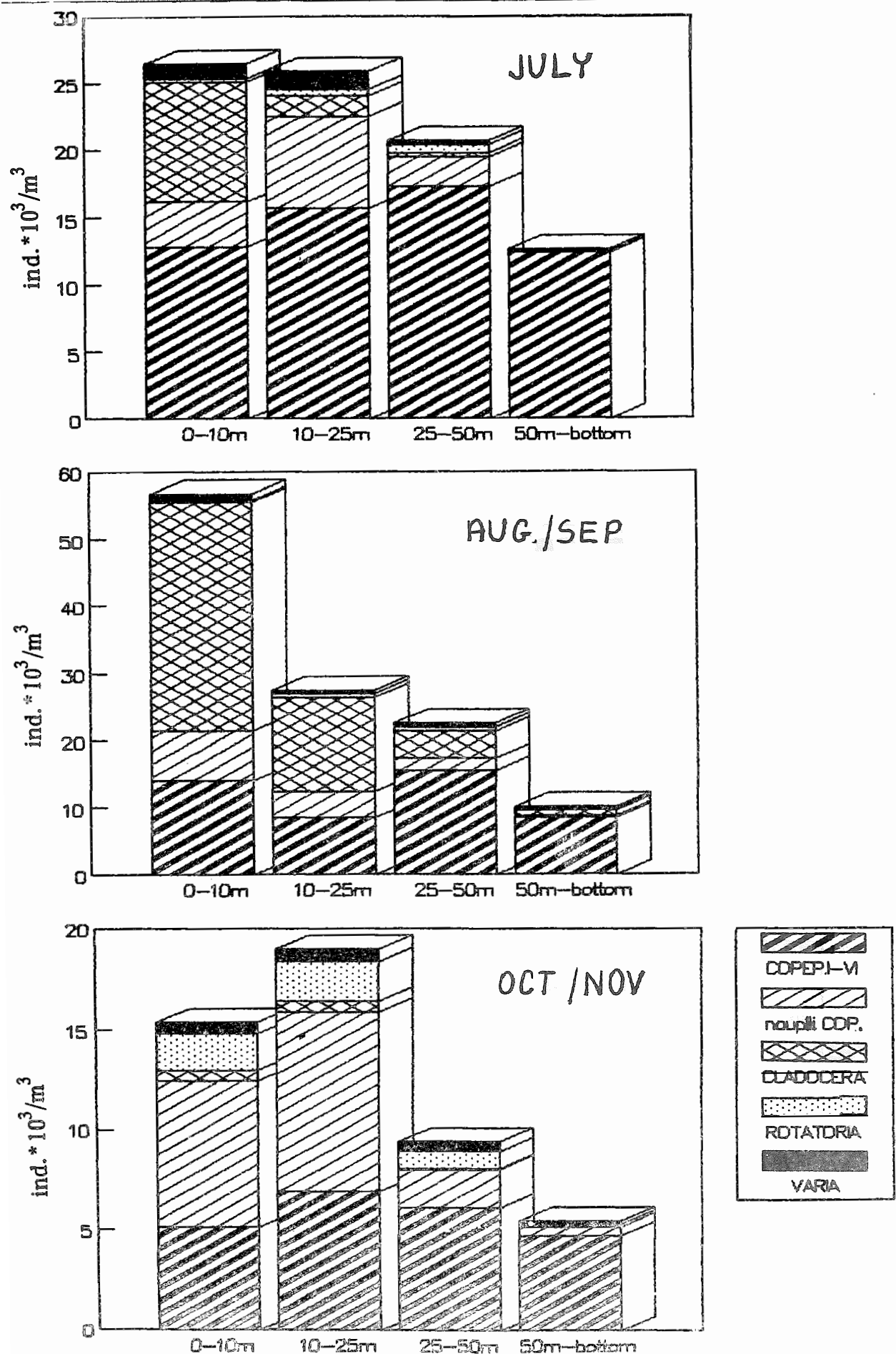

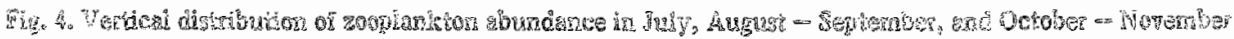


In the surface waters where the seasonal variability in temperature is most pronounced, the abundance of zooplankton shows the highest fluctuations $\left(5-100 \cdot 10^{3}\right.$ ind. $\left./ \mathrm{m}^{3}\right)$. In the 10-50 $\mathrm{m}$ water layer, the temperature was more stable and thus the zooplankton abundance fluctuated less markedly $\left(2-40 \cdot 10^{3} \mathrm{ind} . / \mathrm{m}^{3}\right)$. The highest sta-

\section{a) abundance}
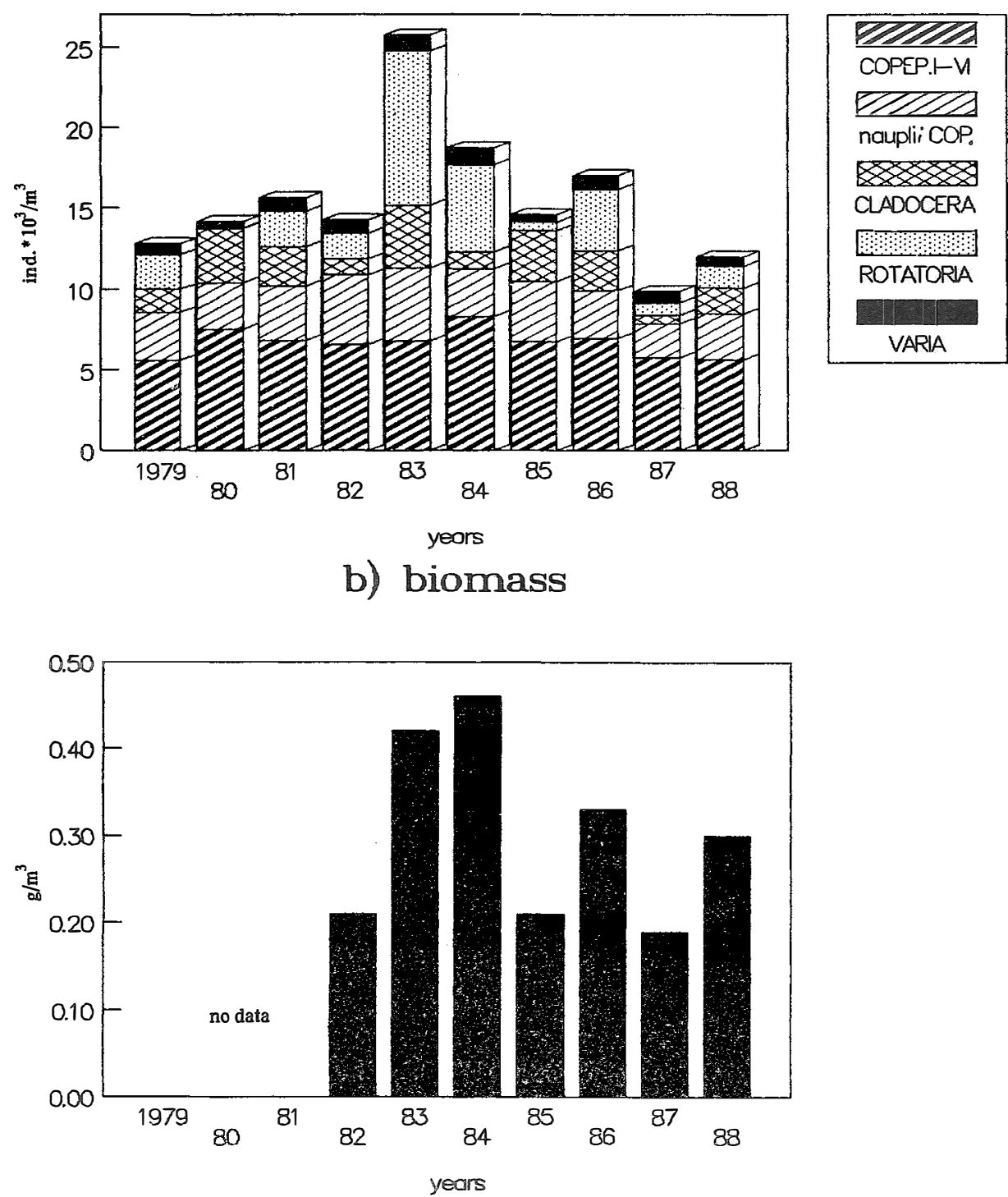

Fig. 5. Mean annual abundance (a) and biomass (b) of zooplankton during the period of 1979-1988 
bility of the zooplankton abundance was observed in the bottom layer $\left(2-10 \cdot 10^{3}\right.$ ind./ $\left./ \mathrm{m}^{3}\right)$. This layer showed also the lowest temperature variations. The largest differences between zooplankton/abundances in the surface and bottom layers were observed in May-June and August-September, i.e. during the mass occurrence of rotifers and cladocerans.

\section{Multiannual variability}

Mean annual values of zooplankton abundance varied considerably from year to year within the 10-year period of study (Fig. 5a). These differences were caused mainly by changes in thermal conditions. An extremely high mean value $\left(26 \cdot 10^{3}\right.$. ind./ $\mathrm{m}^{3}$ ) was recorded in 1983 , while the year 1987 yielded the lowest mean abundance in the 10-year period considered.

The variability resulted predominantly from seasonal differences in quantitative occurrence of single zooplankton taxa such as rotifers and cladocerans, the differences being closely related to changes in water temperature. The copepod abundance showed a great stability during the entire period of study (about $7-11 \cdot 10^{3}$ ind./ $/ \mathrm{m}^{3}$ ) (Fig. 5a).

$\%$
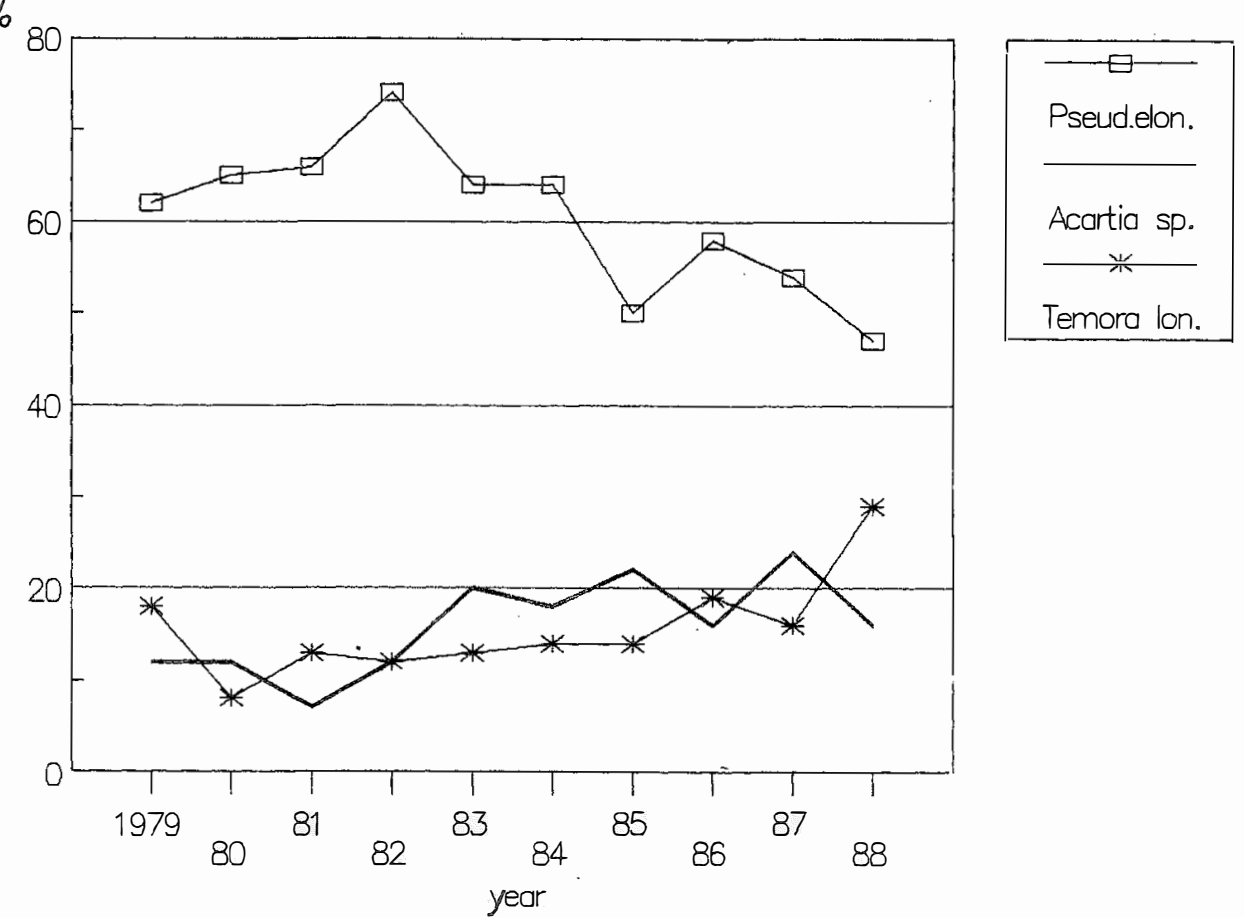

Fig. 6. Changes in per cent contribution of Pseudocalonus elongatus, Temora longicornis, and Acartic sp. in 1979-1988 (per cent of copepod stages 1-i VI in abundance) 
Similarly to abundance, the mean annual biomass varied markedly $\left(0.19-0.46 \mathrm{~g} / \mathrm{m}^{3}\right)$ (Fig. 5b), the variations being closely related to changes in the copepod and cladoceran abundance. Compared with the historical data (Ciszewski 1985; Mańkowski 1978), the mean multiannual biomass for the period of $1982-1988\left(27.1 \mathrm{~g} / \mathrm{m}^{3}\right)$ was high

Changes in the dominance structure among copepods were observed within the recent several years (Fig. 6). Although Pseudocalonus elongatus was the dominant species, its contribution to the copepod abundance decreased from 62-75\% in 19791983 to $47-58 \%$ in 1985-1988. On the other hand, Temora longicornis showed an opposite trend of changesasits contribution increased from 8-14\% in 1980-1985 to 16-29\% in 1986-1988. Similar changes were observed in the genus Acartic (especially Acartia bifilose Giesbrecht), its contribution increasing from 7-12\% in 1979 to $16-24 \%$ in 1983-1988. Różanska (1976) observed similar changes in the coastal waters of the Baltic Sea. She explained a decrease in the contribution of the genus Eurytemore and an increase in that of $A$. bifilosa by a stronger resistance of $A$. bifilosa to pollution or by changes in trophic conditions. It is possible that changes in the abundance of Pseudocalonus elongatus observed in this study were caused by the same factors.

\section{REFERENCES}

Anonymus, 1980: Guidelines for the Baltic Monitoring Programme for the first stage. Part D. Heisinki Commission, Helsinki.

Aronymus, 1984: Guidelines for the Baltic Monitoring Programme for the second stage. Baltic Sea Envir. Proc, $12,259 \mathrm{pp}$.

Ciszewslki Pog 1985: Long-term trends in mesozooplankton biomass development in the southern Baltic. Ocea* nologia, 22: 63-70.

Drzycimski I., K. Siudzinsski, 1977: Zooplankton i ichtioplankton południowego Baftyku. Stud. Mat. MIR Ser. A., 17: 51-70.

Koszteyn J., 1985: Wertykalne zróżnicowanie składu jakościowego i ilościowego mezozooplanktonu w wodach Basenu Gdańskiego i Rynny Słupskiej w lipcu 1980. Stud. Mat. Oceanolog., 46: 203-212.

Manilrowstai W., 1978: Zooplankton Bał̌tyku i jego produktywnos̊ç. In: Produktywnos̊c ekosystemu Morza Bałtyckiego, KBM PAN: 113-134.

Ro̊żånska Z., 1976: Zmiany występowania rodzaju Eurytemora i gatunku Acartia bifilosa w Bałtyku. Stud. Mat. Oceanolog., 15: 259-280.

Author's address:

Institute of Environmental Protection

Gdańsk Branch

Department of Water Ecology

ul. Słupska 25

80-392 Gdańsk

Poland 